\title{
Efficiency analysis of cotton production: a case study of gassol and lau local government of Taraba State, Nigeria
}

\author{
Muhammad Bala ${ }^{1 *}$, Mad Nasir Shamsudin ${ }^{2}$, Alias Radam $^{3}$, dan Ismail Abd. Latif ${ }^{4}$ \\ ${ }^{1,2,4}$ Department of Agribusiness and Information System, Faculty of Agriculture, Universiti Putra \\ Malaysia, UPM Serdang Malaysia \\ ${ }^{3}$ Department of Management and Marketing, Faculty of Economics and Management, Universiti Putra \\ Malaysia, UPM Serdang, Malaysia \\ ${ }^{1}$ Department Agricultural Economics and Extension, Faculty Agricultural Sciences, Taraba State \\ University Jalingo
}

\begin{abstract}
This Study analyzed the efficiency of cotton Production in Gassol and Lau Local Government Areas of Taraba State. Data were collected with the aid of structured questionnaires administered to 81 randomly selected farmers in the study areas and analyzed using descriptive statistics and stochastic frontier production function analysis. The result revealed that majority of farmers $(67.9 \%)$ were young, mostly males $(86.42 \%)$ and educated $(86.41 \%)$. The result of the budgeting technique showed that the total revenue (TR), gross margin (GM), net Farm income (NFI) and Return on Investment (ROI) per hectare were $\$ 55,108.70$, 21, $128.70, \$ 20,008.70$ and $\$ 0.62$ respectively. The result of the stochastic frontier production analysis revealed that the variance parameter indicates positive and significant relationship at $5 \%$ level of probability for agrochemicals and family labour at $1 \%$ level of probability for fertilizer, labour and farm size. Mean technical efficiency index was 0.77 while the minimum and maximum technical efficiency were 0.37 and 0.97 respectively. The study also identified that low price of cotton seed and high cost of inputs are the major challenges faced by cotton producers. The study recommended that inputs should be subsidized by the government and be channeled through the community leaders.
\end{abstract}

\section{Introduction}

Cotton (Gossipium SPP) is a plant grown in warm countries that has a soft white hair around its seed used in textile industries, and of great importance to international trade Korcher, [1], David and Adamu, [2], Helfand, S.M. [3]. Cotton remains the most important natural fibre of the $20^{\text {th }}$ Century that contributed to the development of the Nigeria economy. It is commonly grown under favorable condition like soil type and fertilizer requirements. Nigeria has experienced its peak period in cotton production in 2003/2004 with about 536,400 metric

* Correspondent Author: moh39dbala@gmail.com 
ton output. Since then production has been in decline due to price fluctuation, low farm income, pest infestation and primitive techniques of production, Muhammad, [4].

The Nigeria's output of cotton in 2006/2007 was 631,500 bales, CBN [5]. This shows that compare to that of 2003/2004 a decline in cotton production is being experienced in the country. To blow-away the future occurrence, the Federal Ministry of Science and Technology set up council known as the Raw Materials Research and Development Council, RMRDC [6] to work out ways of implementing the production of some specific crops; and cotton is one of them. According to the council report, it recommended that a collaboration effort has to be made with Afcott Nigeria Plc Yola, Adamawa State, to improve on the cotton seed variety so that high yielding and pest resistant variety would be available to the farmers. Prior to council recommendation, cotton production in Afcott Nigeria Plc, which was established in 1986, has been on the increase. As Mshelia [7] opined, there has been an increase in the average output of farmers as follows: 1.230 tones/ha in 1988, 1.391 tones/ha in 1989 and 1.530 tones/ha in 1990, which in each case compared favorably with the National average of $250 \mathrm{~kg} / \mathrm{ha}$. Further decline in the output of cotton in the recent past made the then Nigerian's president Obasanjo's administration to come up with a new policy on revitalization of textile industries in Nigeria with a capital production taken 20 billion Naira through Cotton Development Committee with Hon. Minister of Agriculture and Rural Development as Chairman of the, CDC [8].

Investigation has shown that there was a decline in cotton production in Nigeria after every four years. This endangered the future prospect of the Nigeria textile industries, which resulted into falling of the country's foreign exchange. The decline may be attributed to the oil boom in seventies, where it becomes prominent and took over from the agricultural sector in terms of relative importance in almost all aspect of Nigeria economic life. Subsequently, the agricultural sector becomes dormant and neglected, Argbokan [9], Aminu, [10]. Prior to the oil boom, cotton was one of the main sources of foreign exchange and the second largest employer of labour after the Government sector, Gbadegesin and Uyoubisere, [11]. Cotton output, in 2010, was almost equivalent to the requirement of the textile industry, USDA, [12]. However, eight years later, cotton production in the country could only account 49 percent of the requirement of the Nigeria textile industry, while the remaining 51 percent was imported, USDA, [12].

Even though, Nigeria is a bonafide member country for international cotton adversary committee ICAC, [13], the quantity of cotton lint required by our spinning industries is always increasing in contrast to the supply, Mshelia, [7]. For Nigeria to maintain a stable domestic need as well as surplus for exportation, effort has to be made towards increasing output and efficiency in cotton production. The decline in the annual growth rate from $61.7 \%$ in 1995 - 1998 was $15.3 \%$ in $1999-2002$ to $4.24 \%$ in $2003-2006$ and to $3.98 \%$ in 2007 2010 should be tackled by the government. This is a matter of the utmost concern, which, if the situation persists, the demand for our local textile industries can hardly be met. Therefore, there is a need to further investigate and analyze the efficiency in cotton production by smallscale farmers as 80 percent of the cotton production in the country is done by them, Ibrahim, [14]. The specific objectives of the study were to:

a) Describe the socio-economic characteristics of cotton farmers in the study areas,

b) Determine the profitability of cotton production,

c) Examine the technical efficiency of factors employed in the production,

d) Analyze the influence of some socio-economic characteristics of farmers on their technical efficiency, and

e) Describe the constraints affecting cotton production in the study areas

\section{Methodology}


The study was conducted in Gassol and Lau Local Government Areas of Taraba State. The state is located in north-eastern part of Nigeria. It is roughly between latitudes $6^{0} 30^{\prime}$ and $9^{0} 36^{\prime} \mathrm{N}$ of the equator and longitudes $9^{0} 11^{\prime}$ and $11^{\circ} 50^{\prime} \mathrm{E}$ of the Greenwich Meridian (Taraba State Government diary, [15]. The state has land area of about $60,291 \mathrm{~km}^{2}$ with a population figure of 2,300,736 people; comprising 1,199,849 males and 1,100,887 females respectively, NPC, [16]. The data was collected from 81 cotton producers, using multi-stage sampling techniques. The sample's respondent was obtained by dividing the multiple of cotton farmers in each district and the total number of the respondent (81) by the number of cotton growers (1350) in the study area. This can be seen in table 2 by using the formula adopted by Adebayo and Olayemi, [17].

Table 1 Distributed Questionnaires in Eight Villages

\begin{tabular}{|l|c|c|}
\hline \multicolumn{1}{|c|}{ Districts } & $\begin{array}{c}\text { Population of } \\
\text { Cotton Growers }\end{array}$ & Questionnaires \\
\hline Abbare & 255 & 15 \\
\hline Lallami & 230 & 12 \\
\hline Lau & 192 & 13 \\
\hline Kunini & 185 & 9 \\
\hline Maihula & 195 & 4 \\
\hline Donadda & 150 & 3 \\
\hline Kurmo & 83 & $\mathbf{8 1}$ \\
\hline Gassol & 60 & 11 \\
\hline Total & $\mathbf{1 3 5 0}$ & \\
\hline
\end{tabular}

Source: Statistical records of Affcott out growers scheme, 2001.

$$
\mathbf{S}=\mathbf{P} / \mathbf{p} \times \mathbf{Q} / \mathbf{1}
$$

Where:

$S=$ Total Number of respondents sampled.

$P=$ Number of cotton farmers at each location.

$\mathrm{p}=$ Total population of cotton farmers in the study area.

$Q=$ Total number the questionnaires to be administered.

\subsection{Method of Data Analysis}

The data collected was subjected to descriptive and inferential statistics. The descriptive statistic was used to achieve objectives one and five of the study. Also, the descriptive statistics, like frequency and percentage was used to describe variables and their occurrences among respondents. Mean was used as a measure of central tendency. Gross Margin analysis gives the difference between the gross income while the total cost of production was used in determining the profitability of cotton production among farmers. The inferential statistics involved the use of stochastic frontier production function to determine the technical efficiency of cotton farmers in the study areas. The gross margin was explicitly stated thus;

$$
\mathbf{G M}=\mathbf{G F I}-\mathbf{T V C}
$$


Where:

$G M=$ Gross Margin ( $\# / H a)$.

$G F I=$ Gross Farm Income ( $)$.

$T V C=$ Total Variable Cost $(\# / H a)$.

$$
\begin{aligned}
& \text { Net return per output }=\text { TR }- \text { TC }(\text { TFC }+ \text { TVC }) Q \\
& \text { NFI }=\text { GM }- \text { TFC }
\end{aligned}
$$

Where:

$N F I=$ Net Farm Income ( $\$ / \mathrm{Ha})$.

$T F C=$ Total Fixed Cost $(\$ / H a)$.

$Q=$ Total Quantity of Cotton $(\mathrm{Kg})$.

\subsubsection{The Stochastic Frontier Production Function}

The use of the stochastic frontier production function has some conceptual advantage in that, it allows for the decomposition of the error term into random error and inefficiency effect rather than attributing all errors to random effects, Xu and Jerry, [18], Ojo, [19].

It is specified as:

$$
Y_{i}=f\left(x_{i} ; \beta\right)+\left(v_{i}-u_{i}\right) \cdot i=\mathbf{1 , 2}
$$

Where:

$Y_{i}=$ an output of the $i^{\text {th }}$ farm

$x_{i}=$ Vector of input quantities of the $i^{\text {th }}$ farm

$\beta=$ Vector of the estimated parameter

$\mathrm{v}_{i}=$ Assumed to account for random factors such as weather, risk and measurement error.

\subsection{The Empirical Stochastic Production Model}

The stochastic frontier production model used was specified as follows: -

$$
\begin{aligned}
\log Y_{i} & =\beta 0+\beta_{1} \log X_{1}+\beta_{2} \log X_{2}+\beta_{3} \log X_{3}+\beta \log X_{4}+\beta_{5} \log X_{5}+\beta_{6} \log X_{6}+\beta_{7} \log X_{7}+\beta 8 \\
& \log X_{8}+v i-u i
\end{aligned}
$$

Where;

$\log Y_{i}=$ output ( $\mathrm{Kg}$ of seed cotton of $i^{\text {th }}$ farmer)

$\mathrm{X}_{1}=$ Total land area under cultivation $(\mathrm{Ha})$

$\mathrm{X}_{2}=$ family labour used in production (in Main days)

$\mathrm{X}_{3}=$ hired labour used in production (in Main days)

$\mathrm{X}_{4}=$ Quantity of Agro-chemicals (in litres) per Ha

$\mathrm{X}_{5}=$ Quantity of fertilizer (in $\mathrm{Kg}$ ) per $\mathrm{Ha}$

$\mathrm{X}_{6}=$ Expenses on ploughing (Animal traction) in naira per $\mathrm{Ha}$

$\mathrm{X}_{7}=$ Quantity of cotton seeds (in $\mathrm{Kg}$ ) per $\mathrm{Ha}$

$\mathrm{X}_{8}=$ depreciation on fixed cost items (in Naira)

$\mathrm{V}_{i}=$ Random noise (white noise) which are the $\mathrm{N}\left(0, \sigma^{2}{ }_{v}\right)$ 
$U i=$ are inefficiency effects which are non-negative, half normal distribution $\mathrm{N}\left(\sigma^{2}{ }_{u}\right)$

Note: The variable $\mathrm{X}_{8}$ (depreciation on fixed cost items) was included because straight line method was used in computing fixed farm assets.

The corresponding cost frontier as used by Ogundari et.al;[21] can be derived analytically and written in general form as;

$$
\mathbf{C}=\mathbf{f}\left(\boldsymbol{\rho}, \mathbf{Y}_{\mathrm{i}}, \gamma_{\mathrm{i}}\right)+\left(\mathbf{V}_{\mathrm{i}}-\mathbf{U}_{\mathrm{i}}\right)
$$

Where;

$C=$ Minimum Cost Used in the production of $Y_{i}$.

$\rho=$ Vector variable of input prices.

$f=$ suitable function form.

$Y_{i}=$ Value of output in $\mathrm{Kg}$.

$\propto_{i}=$ parameter to be estimated.

Using Sheppard's Lemma, Bravo-Ureta and Rieger, [22]; the minimum cost input demand equation is obtained as;

$$
\frac{\delta c}{\delta p}=X(P, Y, Q)
$$

By substituting equation (3.6) and (3.7) into (3.8) yield the economic efficiency of input vector $\mathrm{X}_{\mathrm{e}}$. The technically efficiency input vector $\left(\mathrm{X}_{\mathrm{t}}\right)$ and economically efficient input vector can be used to compute the cost of technically efficient $\left(\mathrm{X}_{\mathrm{t}}, \mathrm{P}\right)$ and economically efficient $\left(\mathrm{X}_{\mathrm{e}}, \mathrm{P}\right)$ input combinations with the firms observed output. The cost of farm's actual operating inputs combination is given as $\left(\mathrm{X}_{\mathrm{a}}, \mathrm{P}\right)$. These three cost measures are the basis for computing the following: technical, economic and allocative efficiency indices as explained by BravoUreta and Rieger, [22].

$$
\begin{aligned}
& T E=E_{t} \frac{P}{X_{e}} \rho \\
& E E=X_{e} \frac{P}{X a} \rho \\
& A E=\frac{E E}{T E}=X_{e} \frac{P}{X t} \rho
\end{aligned}
$$

Where: TE, EE and AE are technical efficiency, economic efficiency and allocative efficiency respectively.

\subsection{The Inefficiency Model}


It is assumed that the technical inefficiency effects are independently distributed and arises by truncation (at zero) of the normal distribution with mean, and variance , where is defined by:

$$
u_{i j}=\lambda_{0}+\lambda_{1} z_{1 i j}+\lambda_{2} z_{2 i j}+\lambda_{3} z_{3 i j}+\lambda_{4} z_{4 i j}+\lambda_{5} z_{5 i j}
$$

Where;

$U_{i j}=$ the technical inefficiency of the farmer

$Z_{1}=$ Years of the farming experience

$Z_{2}=$ Years of formal education

$Z_{3}=$ Extension contact (number of meeting)

$Z_{4}=$ House hold size

$Z_{5}=$ other occupation (where one indicate farming and zero otherwise)

$\lambda_{0}-\lambda_{5}=$ unknown parameters to be estimated)

The maximum likelihood estimates (MLE) of $\beta$ and $\gamma$ coefficients was estimated simultaneously using computer program frontier 4.1 , where the variance parameters are expressed in terms of $\sigma_{\mathrm{s}}{ }^{2}=\sigma_{\mathrm{u}}{ }^{2}+{\sigma_{\mathrm{v}}}^{2}$ and $\gamma=\sigma_{\mathrm{u}}{ }^{2} / \sigma_{\mathrm{s}}{ }^{2}$ (Coelli, [23], Ajibefun, [24] .

\section{Results and Discussions}

\subsection{Socio-Economic Characteristics of the Respondents}

Table1.1 reveals that $67.9 \%$ of the cotton farmers are below the age of 41 years. The mean age of the cotton farmers was 32 years. The preponderance of farmers in the cotton farming profession means that their productivity is expected to be high since they are expected to be active and energetic. This result conformed to Ibrahim [25] who noted in his findings that farmers in their active years are productive and can easily adopt agricultural techniques. The result also shows that most farmers are males $(86.42 \%)$ as against $(13.58 \%)$ females. This indicates that men participate more in cotton production than their female counterparts. The low percentage of women in cotton production may be explained by socio-cultural factors affecting women and not as a result of technical and managerial inefficiencies. The finding reveals that $86.42 \%$ of farmers have family sizes of $1-10$ people in their household while $13.58 \%$ have more than ten (10) people. The mean of the family size was 6 people. The respondents' large family size is above the recommended average of four per family in Nigeria. The large family size is relevant to cotton production because family labour constitutes the highest form of labour supply in cotton production in Nigeria [14].

The study shows that most farmers $(86.41 \%)$ know how to read and write, while only $13.59 \%$ did not attain any form of education. The mean age of schooling is 9 years meaning that most of the farmers have attained education above primary school level. It can be inferred that adoption of farming techniques may be easier as most of them would find it easy to read the specification labeled on the innovations. Consequently, this will help them to access relevant information that will aid in their production, Alabi and Aruna, [26]. The respondents' farming experience indicates that majority $(50.62 \%)$ had 11 years and above, whiles those below 10 years constituted only $(49.37 \%)$. The mean years of experience is about 15 years which is high indicating that cotton farmers are experienced and might know the good practices involved. It is a general opinion that experience farmers would be more efficient, have a better knowledge of climatic conditions and market situations and are expected to run a more efficient and profitable enterprise, Oluwatayo et al, [27]. 
Table 2 Socio-economic characteristics of the respondents

\begin{tabular}{|l|l|l|}
\hline \multicolumn{1}{|c|}{ Socio-economic variables } & \multicolumn{1}{|c|}{ Frequencies } & Percentages \\
\hline Sex & & \\
\hline Male & 70 & 86.42 \\
\hline Female & 11 & 13.58 \\
\hline Age (Years) & & \\
\hline$<30$ & 20 & 24.69 \\
\hline $31-40$ & 35 & 43.21 \\
\hline $41-50$ & 11 & 13.58 \\
\hline$\geq 50$ & 15 & 18.52 \\
\hline Mean & 32 & \\
\hline Household Size & & \\
\hline $1-5$ & 49 & 60.49 \\
\hline $6-10$ & 21 & 25.93 \\
\hline$\geq 11$ & 11 & 13.58 \\
\hline Educational Level & & \\
\hline Non-formal education & 11 & 13.58 \\
\hline Primary school & 20 & 24.69 \\
\hline Secondary & 25 & 30.86 \\
\hline Tertiary & 25 & 30.86 \\
\hline Experience in Years & & \\
\hline $1-5$ & 21 & 25.92 \\
\hline $6-10$ & 19 & 23.45 \\
\hline$\geq 11$ & 41 & 50.62 \\
\hline Total & $\mathbf{8 1}$ & $\mathbf{1 0 0}$ \\
\hline Source: Fiel Surver| & & \\
\hline & & \\
\hline & & \\
\hline
\end{tabular}

Source: Field Survey, 2012.

\subsection{Gross Margin Analysis}

The result in table 1.2 shows that the average variable cost/ha was $\$ 32,860.00$ which represent $96.70 \%$ of the total farming cost while average fixed cost was $\$ 1,120$ which represent $(3.3 \%)$ of the total cost of farming. Thus average selling price $/ \mathrm{kg}$ was $\$ 58.00$ and the total cost of production was $\$ 35.76$ which is the ratio of total cost $(33,980.00)$ to total output per hectare $(950.15)$, i.e. $\left(\frac{33980}{950.15}=35.76\right)$. The Total Revenue (TR), Gross Margin (GM) and Net Farm Income (NFI)/ha of cotton were, $\$ 55,108.70$ [58*950.15], $\$ 22,248.70$ $[55,108.70-32,860.00]$ and $\$ 21,128.70$ [22,248.70-1,120] respectively. From these results, it can be deduced that cotton farming is a profitable venture as the return on investment is N0.62. This finding is in conformity with the finding of Mshelia [7], Ibrahim [25] and Ibrahim [14].

Table 3 Average cost and returns to cotton farmers

\begin{tabular}{|l|rr|}
\hline \multicolumn{1}{|c|}{ Variables } & \multicolumn{1}{c|}{ Value (N) } \\
\hline A. Variable cost & & $32,860.00$ \\
\hline B. Fixed cost & & $1,120.00$ \\
\hline
\end{tabular}




\begin{tabular}{|l|r|}
\hline Total cost of production & $33,980.00$ \\
\hline C. Returns & \\
\hline Total average output (kg) & 950.15 \\
\hline Average price/kg & 58.00 \\
\hline Total revenue & $55,108.70$ \\
\hline Gross margin (TR-TVC) & $22,248.70$ \\
\hline NFI (GM-TFC) & $21,128.70$ \\
\hline Return on naira invested (R.O.I.) & 0.62 \\
\hline Source: Field Survey, 2012. & \\
\hline
\end{tabular}

\subsection{Results of The Stochastic Frontier Production Functions Analysis.}

Table1.3 shows the maximum likelihood estimates of the respondents. The results show that there is positive relationship between variable inputs with output variable. The relationship is also statistical significant at $10 \%$ level for land, labour and for fertilizer while agrochemicals is significance at 5\% level respectively. Fertilizer coefficient has the highest value of 0.47 , followed by family labour and farm size with 0.32 each, and indicated that if more of these variable inputs were use there will be more than proportionate increase in the variable output of cotton. Since fertilizer has the highest coefficient, it means that more fertilizer should be use by the farmers as $1 \%$ increase of it will lead to 0.47 increase in the variable output.

The inefficiency model, as in Table1.3 also, shows that the coefficient of the entire variable had negative sign. Farming experience and visitation by extension agent were statistically significant at 5\%, while literacy level was statistically significant at $1 \%$ level. The negative and significant relationship of the variables in the inefficiency model suggests that inefficiency in production was less among cotton farmers. The signs and coefficients in the inefficiency model are interpreted in the opposite way such that a negative sign decrease inefficiency and positive sign increase inefficiency. This shows that some socio-economic characteristics have influence on the inefficiency of farmers' output. Inefficiency parameters established the fact that inefficiency of cotton production decrease with increases in farming experience. The estimate of variance parameter Sigma Squared $\left(\sigma^{2}=0.82\right)$ is statistically significant at $1 \%$ level of probability and significantly different from zero, indicating a goodness of fit and correctness of the distributional form assumed for the composite error term.

$\operatorname{Gamma}(\gamma=0.56)$ is statistically significant at $1 \%$ shows the amount of variation resulting from the technical inefficiency of the farmers. This means that $56 \%$ of the variation in farmers' output is due to difference in technical efficiency, implying that the ordinary least squares (OLS)) estimate will not be adequate in explaining the inefficiencies on cotton farming. The predicted technical efficiency varies across the respondents, ranging between 0.70 and 0.90 on the scale of maximum one with mean technical efficiency of 0.97 . This implies that cotton producers are $97 \%$ efficient in the use of their input. The return to scale was 1.15 which is greater than one, suggested that the producers of cotton are operating at stage I of the production curve. At this stage, marginal physical product of cotton is greater than the average physical product (MPP >APP), meaning that the rate of inputs used in the production is increasing and it reaches its maximum at the end of stage I. Although, this is a 
rational zone of production yet the point of diminishing returns or efficiency has not been attained. The farmers can only attain that point where Marginal Physical Product (MPP) equals Average Physical Product (APP) (MPP=APP) with elasticity equal to one, i.e. a $1 \%$ change in input will bring about $1 \%$ change in output. This is the point where farmers use optimum amount of variable inputs.

Table 4 Maximum Likelihood of Parameters of Stochastic Productions

\begin{tabular}{|c|c|c|c|}
\hline Variables & Parameters & Coefficient & t-value \\
\hline Constant & $\beta_{0}$ & $0.43 *$ & 0.365 \\
\hline Land $\left(\mathrm{x}_{1}\right)$ & $\beta_{1}$ & $0.32 *$ & 0.298 \\
\hline Labour $\left(\mathrm{x}_{2}\right)$ & $\beta_{2}$ & $0.32 *$ & 0.206 \\
\hline Agrochemical (lit)/h (x3) & $\beta_{3}$ & $0.04 * *$ & 0.213 \\
\hline Fertilizer $(\mathrm{kg}) / \mathrm{h}\left(\mathrm{x}_{4}\right)$ & $\beta_{4}$ & $0.47 *$ & 0.396 \\
\hline \multicolumn{4}{|l|}{ Inefficiency model } \\
\hline Constant & $\delta_{0}$ & $0.27 *$ & -0.298 \\
\hline Farming experience & $\delta_{1}$ & $-0.26^{* *}$ & -0.242 \\
\hline Literacy & $\delta_{2}$ & $-0.61 *$ & -0.393 \\
\hline Extension agent contact & $\delta_{3}$ & $-0.47 * *$ & -0.264 \\
\hline \multicolumn{4}{|l|}{ Variance parameters } \\
\hline Sigma squared & $\sigma^{2}$ & $0.82 *$ & 0.24 \\
\hline Gamma & $\gamma$ & $0.56^{*}$ & 0.37 \\
\hline Minimum TE & 0.37 & & \\
\hline Maximum TE & 0.97 & & \\
\hline Mean TE & 0.77 & & \\
\hline Returns to scale & 1.15 & & \\
\hline
\end{tabular}

\subsection{Frequency Distribution of Technical Efficiency of Cotton Farmers}

Table1.4 shows the frequency distribution of technical efficiency of cotton farmers. The result shows that $80.25 \%$ of the cotton farmers fall to the range of 0.60 and above while, $19.75 \%$ of them fall below the range of 0.60 . The best farmer has a technical efficiency of 0.97 while the worst farmer has a technical efficiency of 0.37 . The mean technical efficiency is 0.77 , meaning that farmers (on average) were able to obtain $77 \%$ optimal output from a given quantity of production inputs. This implies that farmers were not efficient as their observed output was $23 \%$ less than the maximum output. This can be increased by $23 \%$ through improved resource allocation with no additional cost. The magnitude of a mean technical efficiency of the farmers is a reflection of the fact that most of them carry out cotton production under technical condition involving the use of local inputs. The mode of the technical efficiency was 0.97 meaning that majority of the farmers had technical efficiency of 0.97 .

Table 5 Technical efficiency score of cotton farmers

\begin{tabular}{|c|c|r|}
\hline Efficiency Score & Frequency & \multicolumn{2}{|c|}{ Percentage (\%) } \\
\hline $0.30-0.39$ & 4 & 4.94 \\
\hline $0.40-0.49$ & 5 & 6.17 \\
\hline $0.50-0.59$ & 7 & 8.64 \\
\hline $0.60-0.69$ & 25 & 30.86 \\
\hline $0.70-0.79$ & 17 & 20.99 \\
\hline $0.80-0.89$ & 17 & 20.99 \\
\hline $0.90-0.99$ & 6 & 7.41 \\
\hline Minimum 0.37 & & \\
\hline
\end{tabular}




\begin{tabular}{|ll|l|l|}
\hline Maximum & 0.97 & & \\
\hline Mean $\quad 0.77$ & & \\
\hline Mode $\quad 0.97$ & & \\
\hline \multicolumn{2}{|c|}{ TOTAL } & $\mathbf{8 1}$ & \\
\hline
\end{tabular}

\subsection{Constraints associated with Cotton Production.}

From Table1.5, we can see that low price of cotton seeds ranked first as one of the major constraints faced by cotton farmers in the study areas. This represented $21.88 \%$, pest and disease infestation ranked second with $21.09 \%$, while high cost of inputs, inadequate funds, shortage of labour and insufficient extension agents occupied the third, fourth and fifth positions with $19.53 \%, 15.63 \%, 11.72 \%$ and $10.16 \%$ in that order. This finding is in conformity with the work of Dittoh (1980) who worked on output and hectare response to price of cotton and wheat in North-eastern Ghana using time series data and observed that statistical estimate of supply response has been too low because of incorrect formulation of price to which the farmers react. In the same vein, the finding is in line with that of Mshelia [7], Aminu [10] and Ibrahim [25] who, also revealed that cotton farmers respond positively to price of seed of cotton in Adamawa State by cultivating more hectare of land the following year. The high cost of inputs in the study areas may be attributed to low supply of inputs used, especially fertilizer and insecticide which directly affected yield negatively as compared to yield of $1500 \mathrm{~kg}-2000 \mathrm{~kg} / \mathrm{ha}$ by intensified inputs used by its out growers scheme in Adamawa State, Mshelia, [7].

The research also agreed with the findings of Yilmaz and Ozkan [28], who discovered that labour is the most critical factor in cotton production as its insufficient supply in critical period could result in total failure in farming business. The inadequate funds may probably be the reason why farmers could not purchase more of fertilizer and insecticides because of vicious cycle of poverty experienced by most of the peasant farmers in Nigeria. The insufficient extension agent is prevalent in most community of Nigeria today as one hardly see extension agent in villages. Even their demonstration plot or SPAT cannot longer be seen these days instead they are concentrated in towns and cities, where they can enjoy social amenities. This is a threat to agricultural growth and development as most farmers cannot supply correctly some agricultural innovations on their farms that require the attention of the extension agents.

Table 6 Constraints associated with cotton production.

\begin{tabular}{|l|l|l|l|}
\hline Constraints & Frequency & Percentage & Rank** \\
\hline Low price of seed of cotton/Lint & 28 & 21.88 & 1 \\
\hline Pest and Diseases infestation & 27 & 21.09 & 2 \\
\hline High cost of input & 25 & 19.53 & 3 \\
\hline Inadequate credit facilities & 20 & 15.63 & 4 \\
\hline Shortage of labour & 15 & 11.72 & 5 \\
\hline Insufficient extension agent & 13 & 10.16 & 6 \\
\hline
\end{tabular}




\begin{tabular}{|l|l|l|l|}
\hline Total & $128 *$ & 100 & \\
\hline
\end{tabular}

Source: Field Survey, 2012.

* Multiple responses used.

**Ranks in descending order of magnitude.

\section{Conclusion}

The study concludes that the stochastic frontier production function model is the best fit for the data. the study investigated the mutual effect of input on the output variance, whereas the profitability of cotton and technical efficiency were estimated. Results from the analysis recorded that one-naira investment in cotton production will yield 0.62 kobo. The results from the analysis also recorded that technical efficiency enhances the variability of cotton production in the study area with some socioeconomic characteristic influence. The results from the study shows that farmers in the study areas face some constraints in their production processes.

\section{Recommendations}

Based on the farmers' technical efficiency the study recommends that the conventional input factors such as, farm size, fertilizer, agrochemicals and labour are essential in the development of cotton production as they increase output positively in the production process. Therefore, an efforts and actions should be taken to expand efficiency performance at which the cotton farmers operate. Alongside cotton farmers themselves, government should play a fundamental role to improve efficiency through the extension agent to education the farmers on the use of new farming techniques as policy implications to be use by the government to achieve the set objective. Based on the findings of this study, it is recommended that policy action could be taken in order to help enhance cotton output, eradicate technical inefficiencies and tone down its effect in the production process.

\section{References}

1. S.C, Korcher, Tropical Crops, a text book of economic Macmillan Publishers, (New Delhi, India, 1981)

2. G. David and J. Adamu, Crops of the Drier Region of Tropics, (Longman Press. 1991)

3. Helfand, S.M.: Farm Size and the Determinant of Production Efficiency in the Brazilian Centre-West Proceeding of the $25^{\text {th }}$ International Conference of Agricultural Economics, Durban, South Africa, $16^{\text {th }}-22^{\text {nd }}$ August, 2003, Pp 605 - 612, (2003)

4. Muhammad, B. Economic Analysis of Cotton Production in Gassol Local Taraba State. Unpublished PGD Thesis Agricultural Economics, Federal University of Technology, Yola, (2007)

5. CBN: Statistical Bulletin Vol. 18, December (2007)

6. RMRDC, (2004): Report on Survey of selected Agricultural Raw Materials in Nigeria Federal Ministry of Agriculture FCT Abuja, Nigeria.

7. S.I. Mshelia, Economic Analysis of Cotton Production in Nigeria. A Case Study of Afcott Out-growers Scheme in Adamawa State. Unpublished M.Sc. Agric Economics Thesis. University of Ibadan. Pp 15 - 18 (1991) 
8. C.D.C.: Minutes of industrial Meeting of the Cotton Development Committee held at the Ministry's Conference Room, Federal Ministry of Agriculture and Rural

9. Development, Area II Garki, Abuja on Tuesday $30^{\text {th }}$ August 2005.

10. B.E. Argbokam, Resuscitating Agricultural Production (Cocoa, Cotton, Groundnut, Palm oil and Rubber for Export. A paper presented at the $10^{\text {th }}$ Annual Conference of zonalresearch units of the Central Bank of Nigeria, On the theme, Endowment, growth and Macro-Economic Management in Nigeria: held in Oweri: June $4^{\text {th }}-8^{\text {th }}(2001)$

11. S. Aminu, Economic Analysis of Cotton Production in Numan Local Government Area of Adamawa State, Unpublished B. Agric Tech., Agricultural Economics and Extension, Federal University of Technology, Yola, Pp 45 - 46 (2004)

12. R.A. Gbadegesin and E. Uyoubisere, Cotton Production in Nigeria. Extension Bulleting No. 14, Agricultural Extension and Research Liaison Services, Ahmadu Bello University, Zaria, Nigeria (1994)

13. USDA: United State Department of Agriculture, (2018).

14. ICAC: Supply and Distribution of Cotton Worldwide 2(1): 1, (2002)

15. E.J. Ibrahim, Economic of Sole Cotton Production in Lau Local Govt. Area of Taraba State, Nigeria. Unpublished M.Sc. Agric Economics Thesis, Federal University of Technology, Yola. Pp 29 - 40 (2008)

16. Taraba State Official Dairy. Ministry of Education, Taraba State, Nigeria, (2010).

17. National Population Commission, Republic of Nigeria Official Gazette, Printed and Published by the Federal Government Printer, Lagos, Nigeria. No. 24 Vol. 94, $15^{\text {th }}$ May, (2007)

18. E.F. Adebayo and J.K. Olayemi, Application of Goal Programming to Resource Allocation Behaviour of Dairy Producers in Adamawa State, Nigeria. Journal of Sustainable Development and Environment 1: 60 - 69, (2005)

19. X. Xu and S.R. Jeffery, Efficiency and Technical Progress in Traditional and Modern Agriculture Evidence from Rice Production in China Agricultural Economics 18: 157 $165,(1998)$

20. S.O. Ojo and P.B. Imoudu, Productivity and Technical Efficiency: A Comparative Analysis of oil Palm Farms in Ondo State, Journal of Agriculture, Forestry and Fisheries, 1: 40-46, (2000)

21. G.E. Battese and T.J. Coelli, Frontier Production Functions, Technical Efficiency and Panel Data". Journal of Econometrics 38: 387 - 399, (1992)

22. D.K. Orgundari, S.O. Ojo and I.A. Ajibefun, Economics of Scale and Cost Efficiency in Small Maize Production. Empirical Evidences from Nigeria. Journal of Social Sciences 13(2): 131 - 136, (2006)

23. B.E. Bravo-Ureta and L. Reiger, Dairy farm Efficiency Measurement using Stochastic frontier and Neo-Classical Duality. America Journal of Agricultural Economics 73: 421 $-428,(1991)$ 
24. T.J. Coelli, A Guide to Frontier Version 4.1: A Computer Programme for Stochastic Frontier Production and Cost Function Estimation. Department of Econometrics, (University of New England, Armadale, NSW 2351, Australia, 1995)

25. I.A. Ajibefun, Investigation of Technical Inefficiency of Production of Firms Under the National Directorate of Employment in Ondo State, Applied Tropical Agriculture: 3: 15 $-28,(1998)$

26. M.S. Ibrahim, Resource use efficiency in small-scale cotton production in Adamawa State, Nigeria. Unpublished M.Sc Agric Economics Thesis, University of Maiduguri.Pp $50-55,(2002)$

27. R.A. Alabi and M.B. Aruna, Technical efficiency of Family Poultry Production in NigerDelta, Nigeria. Journal of Central European Agriculture, 06 (4): 531-538, (2006)

28. I.B. Oluwatayo, A.B. Sekumade and S.A. Adesoji, Resource Use Efficiency of Maize Farmers in Rural Nigeria: Evidence from Ekiti State. World Journal of Agricultural Sciences. 4(1): 91-99 (2008)

29. I. Yilmaz and B. Ozkan, Economic Analysis of Land Tenure Systems in cotton Production in Turkey, International Journal of Agriculture and Biology 6(60): 10231025, (2004) 